\title{
PENENTU PILIHAN KEBIJAKAN AKUNTANSI PERUSAHAAN (STUDI PADA PERUSAHAAN MANUFAKTUR YANG TERDAFTAR DI BURSA EFEK INDONESIA TAHUN 2015-2017)
}

\author{
Muhammad Zainul Abidin ${ }^{1}$, Ari Budi Kristanto ${ }^{2}$ \\ ${ }^{1,2,3}$ Fakultas Ekonomika dan Bisnis Universitas Kristen Satya Wacana Salatiga \\ e-mail: mzabidin10@gmail.com
}

\begin{abstract}
Abstrak
Penelitian ini bertujuan untuk mengetahui pengaruh ukuran perusahaan, investment opportunity set, leverage keuangan, kompensasi bonus, kepemilikan publik dan tarif pajak efektif terhadap pilihan kebijakan akuntansi. Penelitian ini menggunakan tiga jenis pengukuran kebijakan akuntansi, yaitu : pengukuran persediaan, penyusutan dan aset tetap. Penelitian ini menggunakan 72 sampel perusahaan yang terdaftar di BEI pada tahun 2015-2017. Teknik analisis dalam penelitian ini menggunakan analisis regresi berganda dengan menggunakan SPSS. Hasil penelitian ini menunjukkan investment opportunity set memiliki pengaruh negatif terhadap kebijakan akuntansi, sedangkan kepemilikan publik berpengaruh positif terhadap kebijakan akuntansi. Penelitian ini juga menemukan hasil bahwa ukuran perusahaan, leverage, kompensasi bonus dan tarif pajak efektif tidak memiliki pengaruh terhadap pilihan kebijakan akuntansi.
\end{abstract}

Kata kunci : Kebijakan Akuntansi, Ukuran Perusahaan, Investment Opportunity Set, Leverage Keuangan, Kompensasi Bonus, Kepemilikan Publik, Tarif Pajak Efektif

\begin{abstract}
This study aims to determine the effect of company size, investment opportunity set, financial leverage, bonus compensation, public ownership and effective tax rates on accounting policy choices. This study uses three types of accounting policy measurements, namely: measurement of inventory, depreciation and fixed assets. This study uses 72 samples of companies listed on the Indonesia Stock Exchange in 2015-2017. The analysis technique in this study used multiple regression analysis using SPSS. The results of this study indicate that the investment opportunity set has a negative influence on accounting policies, while public ownership has a positive effect on accounting policies. This study also found that company size, leverage, bonus compensation and effective tax rates had no effect on the choice of accounting policies.
\end{abstract}

Keywords : Accounting Policy, Company Size, Investment Opportunity Set, Financial Leverage, Bonus Compensation, Public Ownership, Effective Tax Rates 


\section{PENDAHULUAN}

Standar Pelaporan Keuangan
Internasional (IFRS) memiliki tujuan agar
laporan keuangan yang disajikan oleh
perusahaan memiliki informasi dengan kualitas
sangat bagus dan dapat diperbandingan.
Dengan dijadikannya IFRS sebagai pedoman
pelaporan keuangan secara global, maka akan
mengurangi terjadinya asimetri informasi dan
akan meningkatkan investasi lintas negara. Namun, IFRS dikritik karena ada juga fleksibilitas di banyak bidang standar dimana lebih dari satu perlakuan akuntansi diperbolehkan (Briginshaw, 2008). Oleh karena itu, manajer perusahaan memiliki kesempatan untuk menggunakan kebijakan akuntansi tertentu agar dapat menguntungkan perusahaan atau menguntungkan manajer.

Fleksibilitas kebijaksanaan manajerial yang terdapat pada IFRS memungkinkan bagi manajer perusahaan memilih menerapkan kebijakan akuntansi yang menguntungkan. Karena alasan oportunistik tersebut, kebijakan akuntansi yang dipilih manajer dapat menimbulkan terjadinya manajemen laba. Dengan fleksibilitas tersebut, manajer dapat memilih untuk menerapkan kebijakan akuntansi yang meningkatkan pendapatan atau menurunkan pendapatan perusahaan.

Kebijakan akuntansi dapat diartikan sebagai aturan, prinsip dan metode akuntansi yang dipilih oleh manajer dari sebuah entitas yang digunakan pihak manajemen sebagai panduan dalam menyusun dan menyajikan laporan keuangan perusahaan. Manajer perusahaan akan menerapkan kebijakan akuntansi yang memberikan keuntungan untuk mencapi tujuan tertentu, sehingga dapat menimbulkan terjadinya manajemen laba (Tala \& Pontoh, 2012). Manajemen laba dapat terjadi karena manajer dan para pembuat laporan keuangan berharap akan mendapatkan manfaat dari tindakan yang dilakukannya (Gumanti, 2000).

Pemilihan kebijakan akuntansi dengan tujuan tertentu dapat menjadi indikasi adanya manipulasi dalam laporan keuangan perusahaan. Salah satu berita terkait dengan hal ini adalah PT Sekawan Intipratama tbk yang menyampaikan laporan keuangan pada september 2015 telah menyajikan laporan keuangan 9 bulanan dengan nilai aset yang jauh berbeda dari laporan keuangan pada bulan Juni 2015. Perbedaan nilai aset yang sangat jauh disebabkan karena adanya penyajian yang berbeda dengan periode sebelumnya.
Dari penelitian sebelumnya, hasil penelitian Utomo (2015) menyatakan bahwa leverage tidak mempengaruhi pemilihan kebijakan akuntansi, risiko tidak mempengaruhi pilihan kebijakan akuntansi, sedangkan bonus plan berpengaruh secara positif terhadap pilihan kebijakan akuntansi perusahaan, Penelitian Ali dan Ahmed (2015) menemukan hasil bahwa ukuran perusahaan, investment opportunity set, leverage keuangan dan kepemilikan oleh masyarakat umum merupakan penentu signifikan dari pilihan kebijakan akuntansi perusahaan di negaranegara Asia Selatan, sedangkan profitabilitas, pajak, dan intensitas modal tidak memiliki pengaruh terhadap pilihan kebijakan akuntansi perusahaan. Penelitian Syailendra dan Rahajra (2014) menemukan bahwa struktur kepemilika saham, variasi persediaan, dan ukuran perusahaan memiliki pengaruh terhadap pilihan metode pencatatan persediaan perusahaan, sedangkan intensitas persedian dan variabilitas laba tidak memiliki pengaruh yang signifikan. Hasil dari penelitianpenelitian sebelumnya mengenai penentu pilihan kebijakan akuntansi perusahaan menunjukkan hasil yang berbeda-beda. Hal ini memberikan motivasi kepada peneliti untuk melakukan penelitian kembali dengan objek perusahaan manufaktur di Indonesia yang secara konsisten terdaftar di BEI pada tahun 2015-2017.

Penelitian ini merupakan replikasi dari penelitian yang sudah dilakukan oleh Ali dan Ahmed (2015). Perbedaan penelitian ini dengan penelitan Ali dan Ahmed (2015) adalah perubahan indikator variabel "bonus plan". Penelitian sebelumnya menggunakan indikator berupa profitabilitas, diganti menjadi kompensasi bonus karena dianggap lebih relevan. Dalam penelitian ini tidak digunakan variabel intensitas modal karena tidak ditemukannya dukungan penelitian terdahulu yang menyatkan intensitas modal berpngaruh terhadap pilihan kebijakan akuntansi perusahaan. Penelitian ini menggunakan objek perusahaan manufaktur yang terdaftar di BEI secara konsisten pada tahun 2015-2017. Adapun tujuan dari penelitian ini yaitu untuk mengetahui apakah ukuran perusahaan, investment opportunity set, leverage keuangan, kompensasi bonus, kepemilikan publik, dan tarif pajak efektif memberikan pengaruh terhadap pilihan kebijakan akuntansi perusahaan.

Persoalan penelitian yang akan dibahas dalam penelitian ini adalah: pertama, apakah ukuran perusahaan berpengaruh terhadap pilihan kebijakan akuntansi? Kedua, apakah 
investment opportunity set berpengaruh terhadap pilihan kebijakan akuntansi? Ketiga, apakah leverage keuangan berpengaruh terhadap pilihan kebijakan akuntansi? Keempat, apakah kompensasi bonus berpengaruh terhadap pilihan kebijakan akuntansi? Kelima, apakah kepemilikan publik berpengaruh terhadap pilihan kebijakan akuntansi? Dan apakah tarif pajak efektif berpengaruh terhadap pilihan kebijakan akuntansi? Penelitian ini diharapkan dapat memberikan manfaat kepada calon investor sebagai informasi tambahan sebelum melakukan keputusan investasi, memberikan manfaat kepada pembuat standar sebagai bahan evaluasi sehingga dapat meningkatkan kualitas laporan keuangan dan memberikan manfaat bagi peneliti selanjutnya sebagai referensi untuk melakukan penelitianpenelitian sekanjutnya.

Kebijakan akuntansi merupakan aturan, prinsip dan metode akuntansi yang dipilih oleh manajer dan digunakan pihak manajemen sebagai landasan dalam menyusun dan menyajikan laporan keuangan perusahaan. Penerapan metode akuntansi yang berbeda dapat memberikan dampak dan hasil yang juga berbeda pada laporan keuangan perusahaan (Syailendra \& Raharja, 2014). Tujuan dari pemilihan kebijakan akuntasi yaitu untuk memastikan agar laporan keuangan dapat memberikan informasi yang relevan, memberikan manfaat bagi penguna laporan keuangan serta memastikan bahwa informasinya dapat diandalkan.

Kebijakan akuntansi dapat dikategorikan menjadi dua, yaitu : kebijakan akuntansi yang meningkatkan pendapatan dan kebijakan akuntansi yang dapat menurunkan pendapatan. Pola income maximization dilakukan manajer perusahaan dengan cara menerapkan kebijakan akuntansi yang memaksimalkan pendapatan perusahaan dengan tujuan agar memperoleh bonus (Astuti, 2009). Ketika manajer meningkatkan laba yang dilaporkan perusahaan, kemakmuran pemegang saham akan meningkat (Lesmana \& Sukartha, 2017). Manajer akan menggunakan kebijakan akuntansi peningkatan pendapatan ketika bonus manajer perusahaan dikaitkan dengan tingkat laba yang dihasilkan perusahaan.

Income minimization merupakan skema yang terapkan oleh manajer perusahaan dengan cara menggunakan kebijakan akuntansi yang dapat menurunkan pendapatan (Astuti, 2009). Dengan laba perusahaan yang semakin rendah, pajak yang dikenakan kepada perusahaan juga akan semakin rendah. Manajer memiliki motivasi untuk melakukan manajemen laba karena dengan menurunkan laba perusahaan biaya pajak yang ditanggung perusahaan akan berkurang (Lesmana \& Sukartha, 2017). Oleh sebab itu, metode akuntansi yang dapat menurunkan pendapatan akan digunakan manajer agar dapat mengurangi biaya pajak perusahaan. Perusahaan yang menerapkan metode rata-rata dalam mencatat persediaan, akan memperoleh laba yang stabil dan cenderung lebih kcil dibandingkan apabila perusahaan menggunakan metode FIFO (Syailendra \& Raharja, 2014).

Menurut Nuraina (2012) ukuran perusahaan adalah banyaknya atau jumlah aset yang dimiliki sebuah perusahaan. Kebijakan akuntansi penurunan pendapatan akan dipilih oleh manajer perusahaan besar karena perusahaan akan memperoleh manfaat berupa penghematan pajak dan menghindari biaya politik yang terlalu besar (Santioso \& Halim, 2013). Perhatian dari publik akan tertuju pada peruahaan besar karena perusahaan dianggap memiliki kinerja yang bagus sehingga biaya politik yang harus ditanggunng perusahaan menjaadi besar. Oleh karena itu, manajer perusahaan cenderung akan menggunakan kebijakan akuntansi penurunan pendapatan agar biaya politik yang ditanggung perusahaan dapat berkurang.

Ukuran perusahaan berpengaruh terhadap kemudahan sebuah perusahaan dalam mendapatkan pinjaman (Nuraina, 2012). Rahmawati dkk (2015) berpendapat bahwa investor pada umumnya menggunakan ukuran perusahaan dalam membuat keputusan investasi. Perusahaan kecil cenderung kurang terlihat dan kurang diminati oleh investor dalam melakukan investasi karena dianggap beresiko dibandingkan dengan perusahaan besar. Untuk memperoleh dana dari investor, perusahaan kecil membutuhkan laba yang besar agar dianggap memiliki kinerja bagus (Santioso \& Halim, 2013). Oleh karena itu, manajer pada perusahaan kecil mungkin akan memilih untuk menerapkan kebijakan akuntansi yang dapat meningkatkan pendapatan perusahaan untuk menarik perhatian investor. Penelitian Syailendra dan Raharja (2014) menemukan bahwa ukuran perusahaan memberikan pengaruh signifikan terhadap pilihan kebijakan akuntansi persediaan. Penelitian Ali \& Ahmed (2015) juga menghasilkan temuan bahwa ukuran perusahaan merupakan penentu dari pilihan kebijakan akuntansi perusahaan. Dengan argumentasi diatas, maka dirumuskan hipotesis pertama yaitu. 
H1: Ukuran perusahaan berpengaruh negatif terhadap pilihan kebijakan akuntansi.

Investment opportunity set (IOS) menggambarkan tentang seberapa luas peluang investasi yang dimiliki sebuah perusahaan dan bergantung pada pilihan pembiayaan demi kepentingan dimasa depan (Sumarni, Yusniar, \& Juniar, 2014). IOS berdampak pada kontrak hutang, struktur modal perusahaan, kebijakan akuntansi perusahaan, kebijakan deviden dan kontrak kompensasi (Dwitayanti \& Fahlefi, 2015). IOS dapat diartikan sebagai kumpulan keputusan investasi dalam bentuk aset yang dimiliki perusahaan dan pilihan investasi untuk masa depan. Saat perusahaan memiliki IOS yang cukup tinggi, maka nilai perusahaan tersebut akan meningkat karena akan ada banyak calon investor yang tertarik untuk menanamkan modal dengan harapan mendapatkan hasil investasi dimasa depan (Jaya \& Wirama, 2017). Perusahaan yang memiliki IOS yang tinggi cenderung akan memiliki tingkat pertumbuhan yang tinggi. Manajer pada perusahaan yang memiliki tingkat pertumbuhan tinggi cenderung memiliki motivasi untuk menurunkan laba perusahaan (Najjar \& Riahi-Belkaoui, 2011). Untuk menghindari terjadinya pelanggaran kontrak dengan investor, manajer mungkin akan memilih membuat perusahaan terlihat mengalami pertumbuhan yang kecil namun dapat dipertahankan untuk beberapa periode kedepan dibandingkan membuat perusahaan mengalami pertumbuhan yang sangat tinggi pada periode saat ini namun tidak mengalami pertumbuhan pada periode selanjutnya. Penelitian Ali \& Ahmed (2015) menemukan hasil bahwa investment opportunity set merupakan penentu dari pilihan kebijakan akuntansi perusahaan. Dengan argumentasi diatas, maka dirumuskan hipotesis ke-dua yaitu.

H2: Investment opportunity set berpengaruh negatif terhadap pilihan kebijakan akuntansi.

Rasio leverage dapat menggambarkan seberapa besar suatu perusahaan dibiayai dengan hutang (Ratnasari \& Budiyanto, 2016). Besarnya sumber pendanaan perusahaan yang diperoleh dari pinjaman dapat diketahui dari leverage keuangan perusahaan yang semakin besar (Utomo R. B., 2015). Perusahaan yang memberikan pinjaman cenderung akan memantau kinerja perusahaan yang sudah melakukan pinjaman agar mengetahui bahwa perusahaan tidak melanggar perjanjian utang (Ali \& Ahmed, 2015). Jika manajer perusahaan melanggar perjanjian utang, akan menimbulkan biaya tambahan berupa biaya hukum dan biaya renegosiasi kontrak utang yang dapat merugikan perusahaan. Manajer memilih menerapkan kebijakan akuntansi peningkatan laba sehingga dapat mencegah timbulnya masalah perlanggaran perjanjian utang (Utomo S. , 2011). Penelitian Ali \& Ahmed (2015) menyatakan bahwa leverage memiliki pengaruh terhadap pilihan kebijakan akuntansi perusahaan. Penelitian Sahputra \& Hidayat (2014) menyatakan bahwa leverage berpengaruh signifikan dan negatif terhadap keputusan manajemen dalam menentukan kebijakan akuntansi perusahaan. Dengan argumentasi tersebut, maka dirumuskan hipotesis ke-tiga yaitu.

H3: Leverage keuangan berpengaruh positif terhadap pilihan kebijakan akuntansi perusahaan.

Kompensasi diberikan oleh perusahaan kepada karyawannya sebagai balas jasa atas pekerjaan yang sudah dilakukan karyawan dan dapat bersifat finansial maupun non finansial. Adapun kompensasi yang biasa diberikan oleh perusahaan kepada karyawan dapat berupa gaji, bonus, dan tunjangan-tunjangan. Manajer perusahaan cenderung ingin menunjukkan kepada pemilik perusahaan bahwa kinerjanya sangat baik dan berharap akan mendapatkan kompensasi berupa bonus (Aprina \& Khairunnisa, 2015). Agar mendapatkan kompensasi bonus, manajer perusahaan cenderung akan menerapkan metode akuntansi yang dapat meningkatkan pendapatan sehingga laba yang dihasilkan menjadi tinggi. Manajer perusahaan yang dijanjikan dengan adanya rencana bonus memungkinkan bagi manajer perusahaan memilih menggunakan kebijakan akuntansi peningkatan pendapatan pada periode berjalan (Utomo S. , 2011). Penelitian Utomo (2015) menemukan bahwa bonus plan berpengaruh positif terhadap pemilihan kebijakan akuntansi. Begitu juga penelitian Utomo (2011) menemukan bahwa skema bonus yang dijanjikan kepada manajer berpengaruh terhadap manajemen laba yang membuat manajer akan menerapkan metode akuntansi peningkatan laba guna memaksimalkan perolehan bonus. Dengan argumentasi diatas, maka dirumuskan hipotesis ke-empat yaitu. 
H4: Kompensasi bonus berpengaruh positif terhadap pilihan kebijakan akuntansi.

Kepemilikan publik merupakan besarnya saham yang dimiliki oleh masyarakat luas. Jika pihak manajemen mempunyai kepemilikan manajerial, kepentingan manajmen akan sama dengan pemegang saham sehingga dapat mengurangi masalah keagenan (Utomo R. B., 2015). Struktur kepemilikan perusahaan dapat memicu sebuah konflik kepentingan yang dapat mempengaruhi pengambilan keputusan (Syailendra \& Raharja, 2014). Kecil kemungkinan bagi pemegang saham pihak luar untuk terlibat dalam kegiatan bisnis perusahaan (Atwinda \& Suryono, 2015). Pada perusahaan yang dimiliki secara luas, pemegang saham tidak mempunyai kemampuan untuk memantau perilaku manajer perusahaan (Ali \& Ahmed, 2015). Oleh karena itu, perilaku manajer tidak dapat dikontrol dan cenderung akan menggunakan kebijakan akuntansi yang menguntungkannya Manajer pada perusahaan yang dimiliki secara luas akan memilih menggunakan metode akuntansi peningkatan pendapatan sehingga kompensasi yang diterima akan menjadi lebih besar (Santioso \& Halim, 2013). Oleh karena itu, manajer pada perusahaan yang dimiliki secara luas cenderung akan menggunakan kebijakan akuntansi yang meningkatkan pendapatan. Dalam penelitiannya, Syailendra \& Raharja (2014) menemukan bahwa struktur kepemilikan saham berpengaruh terhadap pemilihan kebijakan akuntansi persediaan.. Hal yang sama juga ditemukan oleh Ali dan Ahmed (2015) yang mengungkapkan bahwa kepemilikan oleh masyarakat umum merupakan penentu dari pilihan kebijakan akuntasi perusahaan. Dengan argumentasi diatas, maka dirumuskan hipotesis ke-lima yaitu.

H5: Kepemilikan publik berpengaruh positif terhadap pilihan kebijakan akuntansi.

Tarif pajak efektif merupakan rata-rata pajak yang harus dibayarkan oleh perusahaan. Perusahaan dengan tarif pajak efektif yang tinggi menunjukan bahwa pajak yang harus dibayarkan oleh perusahaan juga tinggi. Manajer perusahaan berusaha menekan biaya pajak agar dapat memaksimalkan laba perusahaan (Soepriyanto, 2011). Fields dkk (2001) memberikan pendapat bahwa kebijakan akuntansi tertentu akan dipilih manajer untuk meminimalkan pajak. Jika pada periode sebelumnya perusahaan memiliki tarif pajak efektif yang tinggi, manajer cenderung akan memilih menggunakan kebijakan akuntansi yang dapat menurunkan laba pada periode selanjutnya sehingga perusahaan akan menanggung beban pajak yang lebih kecil. Penelitian Wijaya \& Christiawan (2014) menemukan bahwa pajak berpengaruh terhadap manajemen laba sehingga manajer akan menerapkan metode akuntansi yang dapat menurunkan pendapatan ketika pajak yang dibayarkan besar. Dengan argumentasi diatas, maka dirumuskan hipotesis ke-enam yaitu.

H6: Tarif Pajak Efektif berpengaruh negatif terhadap pilihan kebijakan akuntansi.

\section{METODE}

Penelitian ini merupakan penelitian yang bersifat kuantitatif. Data yang digunakan merupakan data sekunder. Data yang digunakan dalam penelitian ini adalah nilai total aset perusahaan, nilai aset tetap perusahaan, nilai equitas perusahaan, nilai hutang perusahaan, informasi bonus manajer, persentase kepemilikan saham yang dimiliki masayarakat umum, biaya pajak penghasilan, laba bersih sebelum pajak yang dapat diperoleh dari laporan keuangan dan laporan tahunan perusahaan. Adapun laporan keuangan perusahaan diperoleh dari IDX data base (www.idx.co.id).

Populasi dalam penelitian ini yaitu seluruh perusahaan manufaktur yang terdaftar di BEI secara konsisten pada tahun 20152017. Pengambilan sampel dilakukan dengan menggunakan metode purposive sampling dengan kriteria-kriteria sebagai berikut: 1) perusahaan manufaktur yang terdaftar di BEI secara konsisten pada tahun 2015-2017, 2) perusahaan manufaktur yang menerbitkan laporan keuangan yang lengkap dan jelas yang memuat data nilai total aset, nilai aset tetap, nilai equitas, nilai hutang, informasi bonus manajer, persentase kepemilikan saham yang dimiliki masayarakat umum, biaya pajak penghasilan, laba bersih sebelum pajak.

Kebijakan akuntansi merupakan aturan, prinsip dan metode akuntansi yang dipilih oleh manajer dari sebuah entitas yang digunakan sebagai dasar pihak manajemen dalam menyusun dan menyajikan laporan keuangan perusahaan. Penelitian ini menerapkan pendekatan penelitian Ali dan Ahmed (2015) dengan menilai skor pilihan kebijakan akuntansi untuk setiap perusahaan. Penelitian ini memilih tiga pilihan pengukuran akuntansi yaitu persediaan, penyusutan, dan aset tetap. Penelitian ini menggunakan skor antara 1 hingga 2 untuk mengkategorikan pilihan metode akuntansi yang dapat menurunkan pendapatan atau meningkatkan pendapatan. Pilihan metode akuntansi yang dapat 
menurunkan pendapatan akan diberikan skor 1, adapun skor 2 diberikan untuk metode akuntansi yang meningkatkan pendapatan, dan skor 1.5 diberikan untuk penggunaan metode kombinasi.

Tabel 1. Jenis Metode Pengukuran

\begin{tabular}{lll}
\hline Metode Pengukuran & Pilihan Metode & Skor \\
\hline Persediaan & - FIFO & Rata-rata tertimbang $=$ \\
& - Rata-rata tertimbang & $1, \quad$ FIFO = 2, \\
& - Campuran & Campuran $=1,5$ \\
\hline Penyusutan & - Garis lurus & Saldo menurun $=1$, \\
& - Saldo menurun & Garis lurus = 2, \\
& - Campuran & Campuran 1,5 \\
\hline Aset tetap & - Biaya historis & Revaluasi = 1, Biaya \\
& - Revaluasi & historis 2, Campuran \\
& - Campuran & 1,5 \\
\hline
\end{tabular}

Berkaitan dengan pengukuran nilai persediaan, perusahaan dapat memilih menggunakan metode first-in first-out (FIFO), rata-rata tertimbang, atau menggunakan kombinasi dua metode akuntansi antara FIFO dan rata-rata tertimbang. Metode penilaian persediaan yang cenderung lebih disukai oleh manajer adalah metode FIFO, karena metode tersebut dapat meningkatkan laba perusahaan (Syailendra \& Raharja, 2014). Metode FIFO dianggap sebagai metode akuntansi yang dapat meningkatkan pendapatan karena perusahaan yang menggunakan metode FIFO akan memiliki harga pokok penjualan yang rendah, persediaan akhir memiliki nilai yang tinggi dan menghasilkan laba kotor yang cenderung lebih tinggi dari pada apabila perusahaan menggunakan metode rata-rata tertimbang. Perusahaan besar memiliki kecenderungan untuk memilih menggunakan metode rata-rata tertimbang karena dapat menurunkan laba, sehingga perusahaan dapat memperoleh penghematan pajak dan juga mengurangi biaya politik (Syailendra \& Raharja, 2014).

Dalam menyusutkan aset perusahaan, manajer perusahaan dapat memilih untuk menggunakan metode penyusutan garis lurus, saldo menurun, atau menggunakan kombinasi dari kedua metode tersebut. Penggunaan metode garis lurus akan menghasilkan nilai penyusutan yang sama setiap tahunnya hingga umur ekonomisnya habis, sedangkan metod saldo menurun dapat menghasilkan nilai penyusutan lebih tinggi pada periode awal penyusutan namun akan terus mengalami penurunan nilai penyusutan pada tahun berikutnya hingga umur ekonomisnya habis. Penggunaan metode penyusutan garis lurus akan menghasilkan nilai beban penyusutan yang lebih rendah pada saat awal penyusutan, sehingga akan meningkatkan pendapatan.

Dalam menilai aset tetap, perusahaan dapat memilih menggunakan nilai historis, melakukan revaluasi, atau kombinasi dari nilai historis dan revaluasi. Perusahaan yang melakukan revaluasi akan mengakibatkan nilai aset bertambah dan menyebabkan adanya biaya penyusutan yang lebih tinggi dibanding jika tidak melakukan revaluasi. Metode revaluasi dianggap menurunkan pendapatan karena adanya biaya penyusutan yang lebih besar dibanding hanya menggunakan nilai historis.

Tabel 2. Definisi Operasional dan Pengukuran Variabel Bebas

\begin{tabular}{|c|c|c|}
\hline Variabel & Definisi Operasional & Pengukuran \\
\hline Ukuran Perusahaan & $\begin{array}{l}\text { Ukuran perusahaan merupakan banyaknya } \\
\text { atau jumlah aset yang dimiliki perusahaan } \\
\text { (Nuraina, 2012). }\end{array}$ & $\begin{array}{l}\text { Nilai buku total aset } \\
\text { pada akhir tahun }\end{array}$ \\
\hline \multirow{3}{*}{$\begin{array}{l}\text { Investment } \\
\text { Opportunity Set }\end{array}$} & IOS merupakan kumpulan keputusan & AT \\
\hline & $\begin{array}{l}\text { investasi dalam bentuk aset yang dimiliki } \\
\text { perusahaan dan pilihan investasi masa }\end{array}$ & $(\mathrm{NE}+\mathrm{NU})$ \\
\hline & depan. & $\begin{array}{l}\mathrm{AT}=\text { Nilai bruto aset } \\
\text { tetap } \\
\mathrm{NE}=\text { Nilai pasar equitas } \\
\mathrm{NU}=\text { Nilai buku hutang }\end{array}$ \\
\hline
\end{tabular}




\begin{tabular}{|c|c|c|}
\hline Leverage Keuangan & $\begin{array}{l}\text { Leverage keuangan merupakan rasio yang } \\
\text { digunakan untuk mengukur seberapa besar } \\
\text { perusahaan dibiayai dengan pinjaman } \\
\text { (Ratnasari \& Budiyanto, 2016). }\end{array}$ & $\begin{array}{l}\mathrm{TU}=\text { Total utang } \\
\mathrm{NT}=\text { Nilai buku dari total } \\
\text { aset berwujud }\end{array}$ \\
\hline Kompensasi Bonus & $\begin{array}{l}\text { Kompensasi bagi manajer merupakan balas } \\
\text { jasa yang diberikan oleh perusahaan } \\
\text { terhadap karyawannya yang dapat berupa } \\
\text { gaji, bonus, dan tunjangan. Variabel ini } \\
\text { diukur dengan menggunakan variabel } \\
\text { dummy seperti pada penelitian (Utomo S. } \\
\text { 2011). }\end{array}$ & $\begin{array}{l}\text { Skor } 1=\text { apabila ada } \\
\text { skema } \\
\text { bonus. } \\
\text { Skor } 0=\text { apabila tidak } \\
\text { ada skema kompensasi } \\
\text { bonus. }\end{array}$ \\
\hline Kepemilikan Publik & $\begin{array}{l}\text { Kepemilikan publik merupakan jumlah saham } \\
\text { perusahaan yang dimiliki oleh masyarakat } \\
\text { umum. }\end{array}$ & $\begin{array}{l}\text { Persentase kepemilikan } \\
\text { saham yang dipegang } \\
\text { oleh masyarakat umum }\end{array}$ \\
\hline Tarif Pajak Efektif & $\begin{array}{l}\text { Tarif pajak efektif merupakan tingkat rata-rata } \\
\text { pajak yang harus dibayarkan oleh } \\
\text { perusahaan. }\end{array}$ & $\frac{\text { Pajak Penghasilan }}{\text { Laba Bersih Sebelum Pajak }}$ \\
\hline
\end{tabular}

\section{Teknik dan Analisis}

Metode analisis yang digunakan dalam penelitian ini adalah model regresi linear berganda, dengan model sebagai berikut.

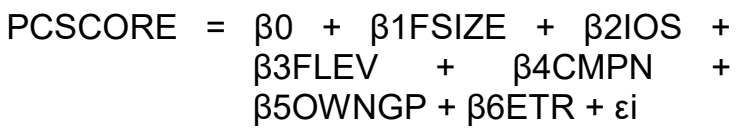

PCSCORE = skor pilihan kebijakan akuntansi

FSIZE = ukuran perusahaan

IOS = investment opportunity set

FLEV = leverage keuangan

CMPN = kompensasi bonus

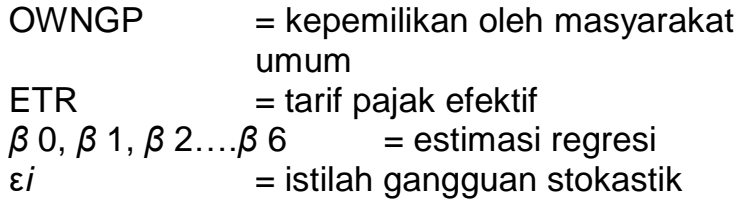

\section{HASIL DAN PEMBAHASAN}

Perusahaan manufaktur yang terdaftar di BEI pada tahun 2015-2017 merupakan populasi dari penelitian ini dan sampel dipilih dengan menggunakan metode purposive sampling, sehingga diperoleh sampel perusahaan sebanyak 72 perusahaan.

Tabel 3. Hasil Seleksi Sampel Perusahaan

\begin{tabular}{lll}
\hline No & Keterangan & Jumlah \\
\hline 1 & Perusahaan manufaktur yang tercatat di BEI tahun 2015-2017 & 143 \\
2 & Perusahaan manufaktur yang tidak tercatat di BEI secara berturut- & $(11)$ \\
3 & turut pada tahun 2015-2017 & $(60)$ \\
4 & Perusahaan yang mengalami kerugian selama periode penelitian & 72 \\
5 & Jumlah sampel perusahaan & 3 \\
Total data penelitian & 216 \\
\hline
\end{tabular}

Sumber : Data penelitian (2019)

Tabel 4. Statistik Deskriptif

\begin{tabular}{lllll}
\hline Variabel & Minimum & Maximum & Mean & Standar Deviasi \\
\hline Kebijakan Akuntansi & 1,17 & 2,00 & 1,64 & 0,15 \\
Ukuran Perusahaan (Rp 000,000 ) & 169.546 & 91.831 .500 & 8.344 .882 & 15.470 .139 \\
IOS & 0,02 & 3,08 & 0,58 & 0,52 \\
Leverage & 0,18 & 12,35 & 1,39 & 1,31 \\
Kompensasi Bonus & 0,00 & 1,00 & 0,94 & 0,22 \\
\hline
\end{tabular}




\begin{tabular}{lllll}
\hline Kepemilikan Publik & $1 \%$ & $71 \%$ & $25 \%$ & $15 \%$ \\
Tarif Pajak Efektif & 0,06 & 0,92 & 0,28 & 0,13 \\
\hline
\end{tabular}

Berdasarkan Tabel statistik deskriptif untuk variabel kebijakan akuntansi, skor ratarata sebesar 1,64 sementara skor minimal dan maksimal sebesar 1,17 dan 2,00. Nilai tersebut menunjukkan bahwa lebih banyak perusahaan menggunakan kebijakan akuntansi yang meningkatkan pendapatan dari pada yang menurunkan pendapatan. Nilai perusahaan paling kecil adalah $\mathrm{Rp}$ 169.546.066.314 sedangkan paling besar adalah $\mathrm{Rp}$ 91.831.500.000.000. Nilai tersebut menunjukkan adanya perbedaan aset yang sangat banyak antara perusahaan yang paling kecil dan perusahaan paliing besar. Rata-rata nilai IOS perusahaan sebesar 0,58 yang dapat diartikan bahwa aset bruto perusahaan kurang dari nilai ekuitas dan total utang. Nilai tersebut menunjukkan kelayakan perusahaan sebagai tempat investasi masih rendah. Untuk variabel leverage, skor rata-rata sebesar 1,3916 yang menunjukkan perusahaan bergantung dengan utang. Nilai variabel kompensasi bonus memiliki skor rata-rata sebesar 0,9444 yang menunjukkan bahwa mayoritas perusahaan memberikan kompensasi bonus kepada manajer. Untuk kepemilikan publik tertinggi sebesar $71 \%$ yang menggambarkan perusahaan melepas mayoritas sahamnya kepada masyarakat umum. Sedangkan kepemilikan publik terendah sebesar $1 \%$. Berdasarkan nilai rata-rata untuk tarif pajak efektif perusahaan, pajak yang dibayarkan perusahaan cukup tinggi karena harus membayarkan $28 \%$ dari laba bersih sebelum pajak.
Penelitian ini sudah lolos dalam uji asumsi klasik dengan lolos pada uji normalitas, uji heteroskedastisitas, uji multikolinearitas dan uji autokorelasi. Untuk uji normalitas, pengujian menggunakan Normal P-P Plot, hasilnya menunjukkan bahwa titik-titik menyebar disekitar garis diagonal dan mengikuti arah garis diagonal. Uji heteroskedastisitas dilakukan dengan menggunakan scatterplot dengan hasil menunjukkan persebaran titik-titik data berada diatas dan dibawah angka nol pada sumbu Y. Berdasarkan hasil pengujian multikolinearitas, diketahui bahwa VIF untuk semua variabel memiliki nilai $\leq 10$, sedangkan nilai tolerance untuk semua variabel adalah $\geq 0,10$. Berdasarkan hasil uji autokorelasi dengan menggunakan tabel Durbin Watson, untuk $\mathrm{n}=216$ dan $\mathrm{k}=7$ pada level alpha $5 \%$ diperoleh nilai $\mathrm{dL}=1,7156$ dan nilai $\mathrm{dU}=1,8330$, nilai 4 $\mathrm{dU}=2,1670$, sedangkan nilai DW dalam penelitian ini adalah 2,031. Oleh karena itu nilai $\mathrm{dU}=1,8330<\mathrm{DW}=2,031<(4-\mathrm{dU})=$ 2,1670.

Pengujian hipotesis dalam penelitian ini menggunakan analisis regresi berganda untuk mengetahui pengaruh antara ukuran perusahaan, IOS, leverage keuangan, kompensasi bonus, kepemilikan publik dan tarif pajak efektif terhadap pilihan kebijakan akuntansi perusahaan. Berikut ini merupakan hasil analisis regresi berganda dalam penelitian ini.

Tabel 5. Hasil Uji Hipotesis

\begin{tabular}{llc}
\hline Model & $\mathrm{B}$ & Sig. \\
\hline Ukuran Perusahaan & 0,001 & 0,828 \\
Invesment Opportunity Set & $-0,001$ & $0,084^{* *}$ \\
Leverage keuangan & 0,002 & 0,489 \\
Kompensasi Bonus & 0,004 & 0,746 \\
Kepemilikan Publik & 0,038 & $0,044^{*}$ \\
Tarif Pajak Efektif & $-7,268$ & 0,961 \\
\hline
\end{tabular}

R : 0,20

** Signifikan pada tingkat $10 \%$

* Signifikan pada tingkat 5\%

Berdasarkan hasil analisis regresi berganda, didapatkan hasil bahwa ukuran perusahaan, leverage, kompensasi bonus dan tarif pajak efektif berpengaruh tidak signifikan terhadap pilihan kebijakan akuntansi. Sedangkan IOS dan tarif pajak efektif memiliki pengaruh terhadap pilihan kebijakan akuntansi dengan arah negatif dan positif. Ketika perusahaan memiliki IOS yang tinggi, manajer perusahaan akan menggunakan kebijakan akuntansi yang menurunkan pendapatan. Sedangkan ketika kepemilikan publik tinggi, manajer perusahaan cenderung akan menggunakan kebijakan akuntansi yang meningkatkan pendapatan. Berdasarkan nilai $R$, variabel dependen dipengaruhi secara 
simultan oleh variabel independen sebesar 20 persen.

\section{Pembahasan}

Berdasarkan pengujian hipotesis didapatkan hasil bahwa ukuran perusahaan tidak mempengaruhi pilihan kebijakan akuntansi, sehingga hipotesis pertama dalam penelitian ini ditolak. Penelitian ini memberikan temuan yang berbeda dari penelitian Ali \& Ahmed (2015) yang menyatakan bahwa ukuran perusahaan berpengaruh positif terhadap kebijakan akuntansi. Alasan yang masuk akal dengan hasil ini adalah karena ukuran perusahaan hanya menggambarkan total aset, sedangkan calon investor tidak akan membuat keputusan investasi hanya dengan melihat berapa banyak nilai aset yang dimiliki perusahaan. Calon investor akan melakukan analisis keuangan dengan menggunakan berbagai rasio keuangan untuk menilai kinerja perusahaan. Dengan argumen tersebut, ukuran perusahaan tidak akan mempengaruhi kebijakan akuntansi yang dipilih oleh manajer karena meningkatkan jumlah aset perusahaan tidak memberikan jaminan perusahaan akan mendapatkan calon investor.

Berdasarkan pengujian hipotesis didapat bahwa IOS berpengaruh negatif terhadap kebijakan akuntansi, maka hipotesis kedua dalam penelitian ini diterima. Hasil penelitian ini sejalan dengan penelitian Astami \& Tower (2006) yang menemukan bahwa IOS berpengaruh negatif terhadap kebijakan akuntansi perusahaan. Ketika perusahaan memiliki nilai IOS yang cukup tinggi, perusahaan akan mengalami pertumbuhan yang tinggi sehingga akan ada banyak calon investor yang tertarik untuk menanamkan modal pada perusahaan tersebut dengan harapan mendapatkan hasil investasi dimasa depan. Dengan menggunakan kebijakan akuntansi yang menurunkan pendapatan, manajer perusahaan dapat membuat perusahaan memperoleh laba yang rendah dengan cara menahan laba untuk dilaporkan pada periode selanjutnya. Sehingga perusahaan akan memperoleh laba yang stabil pada periode-periode selanjutnya dan menghindari terjadinya masalah kontrak dengan investor.

Berdasarkan pengujian hipotesis didapat bahwa leverage keuangan tidak berpengaruh terhadap kebijakan akuntansi, maka hipotesis ketiga dalam penelitian ini ditolak. Penelitian ini memberikan hasil yang berbeda dengan penelitian Ali \& Ahmed (2015) yang menemukan hubungan negatif antara leverage dengan kebijakan akuntansi. Menurut Tala \&
Pontoh (2012) kebijakan hutang dapat menjadi alternatif sumber pendanaan perusahaan dan apabila digunakan secara efektif dan efisien akan meningkatkan nilai perusahaan. Alasan yang membuat leverage tidak mempengaruhi manajer dalam memilih kebijakan akuntansi adalah karena manajer mampu mengelola hutang dengan efektif dan efisien sehingga perusahaan masih mampu melunasi kewajiban kepada kreditur dengan tepat waktu dan sesuai jumlah yang seharusnya dibayarkan sehingga tidak terjadi pelanggaran kontrak.

Berdasarkan pengujian hipotesis didapat bahwa kompensasi bonus tidak berpengaruh terhadap kebijakan akuntansi, maka hipotesis keempat dalam penelitian ini ditolak. Penelitian ini menunjukkan hasil yang berbeda dengan penelitian Utomo (2015) yang menyatakan bahwa kompensasi bonus berpengaruh positif terhadap kebijakan akuntansi. Teori agensi menjelaskan hubungan antara prinsipal yang merupakan pemilik dan manajer sebagai agen (Tala \& Pontoh, 2012). Pemegang saham memiiki keinginan untuk memperoleh keuntungan yang sebesar-besarnya atas investasi mereka didalam perusahaan. Untuk mendapatkan keuntungan yang besar, pemegang saham selaku prinsipal menerapkan sekema bonus bagi manajer agar termotivasi dan berusaha keras agar perusahaan mendapatkan keuntungan yang besar. Namun, manajer tidak akan selalu termotivasi dengan adanya kompensasi bonus. Target yang sulit dicapai bisa menjadi alasan manajer untuk tidak mengejar bonus. Oleh karena itu, kompensasi bonus tidak akan mempengaruhi manajer dalam memilih kebijakan akuntansi.

Berdasarkan pengujian hipotesis didapat bahwa kepemilikan publik berpengaruh positif terhadap kebijakan akuntansi, maka hipotesis kelima dalam penelitian ini diterima. Hasil penelitian ini sejalan dengan penelitian Ali \& Ahmed (2015) yang menyatakan bahwa kepemilikan saham oleh masyarakat umum berpangaruh positif terhadap kebijakan akuntansi. Dengan adanya komposisi pemegang saham publik sangat tinggi, perilaku manajer didalam perusahaan tidak dapat dikontrol karena pemegang saham tidak mempunyai kemampuan untuk mengawasi manajer. Hal ini memungkinkan manajer perusahaan memilih menerapkan kbijakan akuntansi peningkatan pendapatan sehingga laba yang hasilkan menjadi tinggi. Dengan diperoleh laba perusahaan yang tinggi, manajer akan dianggap memiliki kinerja bagus, sehingga insentif yang akan diterima manajer bisa lebih besar. 
Berdasarkan pengujian hipotesis didapat bahwa tarif pajak efektif tidak berpengaruh terhadap kebijakan akuntansi, sehingga hipotesis ditolak. Hasil penelitian ini sejalan dengan penelitian Ali \& Ahmed (2015) yang menemukan bahwa tarif pajak efektif tidak berpengaruh terhadap kebijakan akuntansi. Menurut Agoes dkk (2010) rekonsiliasi fiskal merupakan penyesuaian atas laba komersil yang berbeda dengan dengan ketentuan fiskal yang digunakan untuk mengetahui pendapatan neto perusahaan yang sesuai dengan ketentuan perpajakan. Dengan adanya rekonsiliasi fiskal, maka pajak yang harus dibayaran perusahaan tidak bergantung dari laba komersil. Alasan tarif pajak efektif yang tinggi tidak berpengaruh terhadap pemilihan kebijakan akuntansi adalah karena pajak yang dibayarkan perusahaan berdasarkan rekonsilisasi fiskal. Penggunaan metode akuntansi tertentu hanya akan mempengaruhi laporan keuangan secara komersil dan tidak mempengaruhi pajak yang harus dibayarkan berdasarkan rekonsiliasi fiskal.

\section{PENUTUP}

Tujuan dari penelitian ini adalah untuk menguji faktor penentu pilihan kebijakan akuntansi pada perusahaan manufaktur yang terdaftar di BEl tahun 2015 sampai 2017. Penelitian ini menggunakan tiga jenis pengukuran kebijakan akuntansi, yaitu : pengukuran persediaan, penyusutan dan aset tetap. Berdasarkan hasil penelitian, dapat disimpulkan bahwa IOS berpengaruh negatif terhadap kebijakan akuntansi, sedangkan kepemilikan publik berpengaruh positif terhadap kebijakan akuntansi. Penelitian ini juga menemukan hasil bahwa ukuran perusahaan, leverage keuangan, kompensasi bonus dan tarif pajak efektif tidak memiliki pengaruh terhadap pilihan kebijakan akuntansi. Hasil dari penelitian ini dapat memberikan manfaat kepada pembuat standar sebagai bahan evaluasi atas kebijakan yang sudah ditetapkan sehingga dapat memberikan peningkatkan pada kualitas laporan keuangan.

mengatasi keterbatasan dalam penelitian ini dengan mendapatkan informasi lebih akurat, misalnya dengan bertanya dengan perusahaan terkait mengenai ada atau tidaknya kompensasi bonus bagi manajer.

Berdasarkan penelitian yang sudah dilakukan maka saran yang bisa penulis berikan yaitu: peneliti selanjutnya diharapkan mampu mengatasi keterbatasan dalam penelitian ini, dan dapat memperluas objek penelitian pada perusahaan selain manufaktur karena adanya jenis dan variasi persediaan yang berbeda dengan perusahaan manufaktur.

\section{DAFTAR PUSTAKA}

Agoes, Sukrino, \& Trisnawati, E. (2010). Akuntansi Perpajakan, Edisi 2 Revisi. Salemba Empat, Jakarta.

Ali, M. J., \& Ahmed, K. (2015). Determinants of accounting policy choices under International Accounting Standards: evidence from South Asia. Accounting Research Journal.

Aprina, D. N., \& Khairunnisa. (2015). Pengaruh ukuran perusahaan, profitabilitas, dan kompensasi bonus terhadap manajemen laba (Studi kasus pada perusahaan perdagangan, jasa, dan investasi sub sektor perdagangan eceran yang terdaftar di bursa efek Indonesia tahun 2012-2014). e-Proceeding of Management, 2(3) : 3251-3258.

Astami, E. W., \& Tower, G. (2006). Accounting policy choice and firm characteristics in the asia pacific regipn: An international empirical test. The international journal of accounting, 41, 1-21.

Astuti, D. P. (2009). Review penelitian tentang earnings management terhadap kinerja perusahaan. Jurnal Akuntansi dan Sistem Teknologi Informasi, 7(1) : 37-49.

Atwinda, D. R., \& Suryono, B. (2015). Pengaruh keuangan, kualitas auditor, kepemilikan perusahaan terhadap penerimaan opini audit going concern. Jurnal IImu \& Riset Akuntansi, 4(8) : 1-20.

Briginshaw, J. (2008). What Will The International Financial Reporting Standards (IFRS) Mean to Businesses and Investors? Graziadio Business Review, 11(4).

Cloyd, C. B., Pratt, J., \& Stock, T. (1996). The use of financial accounting exchequed keterbatasan dala support aggressive tax positions: public and private firms. Journal of Accounting Research, 34(1) : 23-43.

Dwitayanti, Y., \& Fahlefi, R. (2015). Pengaruh kepemilikan manajerial, investment opportunity set (IOS), price to book ratio dan political cost terhadap konservatisma akuntansi. Jurnal Akuntanika, 1(2) : 3143. 
Fields, T. D., Lys, T. Z., \& Vincent, L. (2001). Empirical research on accounting. Journal of Accounting and Economics, 31 : 255307.

Gibson, C. H. (2001). Financial Reporting and Analysis: Using Financial Accounting Information. USA: South Western: Thomson Learning.

Gumanti, T. A. (2000). Earnings management: Suatu telaah pustaka. Jurnal Akuntansi dan Keuangan, 2(2): 104-115.

Hagerman, R. L., \& Zmijewski, M. E. (1979). Some economic determinants of accounting policy choice. Journal of accounting and economics, 1 : 141-161.

Ichwan, F. Y., \& Widyawati, D. (2015). Pengaruh ukuran perusahaan, struktur aktiva dan profitabilitas terhadap struktur modal. Jurnal IImu dan Riset Akuntansi, 4(6) : 1-19.

Jaya, K. A., \& Wirama, D. G. (2017). Pengaruh investment opportunity set, likuiditas, dan ukuran perusahaan pada kualitas laba. EJurnal Akuntansi Universitas Udayana, 21(3): 2195-2221.

Lesmana, I. S., \& Sukartha, I. M. (2017). Pengaruh manajemen laba pada nilai perusahaan manufaktur yang terdaftar di bursa efek Indonesia tahun 2012-2015. E-Jurnal Akuntansi Universitas Udayana, 19(2) : 1060-1087.

Najjar, F. K., \& Riahi-Belkaoui, A. (2011). Empirical validation of a general model of growth opportunities. Managerial Finance, 27(3) : 72-88

Nuraina, E. (2012). Pengaruh kepemilikan institusional dan ukuran perusahaan terhadap kebijakan hutang dan nilai perusahaan (Studi pada perusahaan manufaktur yang terdaftar di BEI). Jurnal Bisnis dan Ekonomi, 19(2) : 110-125.

Rahmawati, A. D., Topowijono, \& Sulasmiyati, S. (2015). Pengaruh ukuran perusahaan, profitabilitas, struktur modal dan keputusan investasi terhadap nilai perusahaan ((studi pada perusahaan sektor properti, real estate, dan building construction yang terdaftar di bursa efek Indonesia (BEI) periode 2010-2013). Jurnal Administrasi Bisnis, 23(2) : 1-7.
Ratnasari, L., \& Budiyanto. (2016). Pengaruh leverage, likuiditas, ukuran perusahaan terhadap profitabilitas pada perusahaan otomotif di BEI. Jurnal IImu dan Riset Manajemen, 5(6) : 1-15.

Ruroh, I. N., \& Latifah, S. W. (2018). PENGARUH PROFITABILITAS, LEVERAGE, UKURAN PERUSAHAAN DAN RISK MINIMIZATION TERHADAP PENGUNGKAPAN CORPORATE SOCIAL RESPONSIBILITY (CSR) (Studi Empiris Pada Perusahaan Pertambangan Yang Terdaftar Di Bei Periode 20152016). Jurnal Akademi Akuntansi.

Sahputra, J. H., \& Hidayat, T. (2014). Motivation on accounting choice of actuarial gain (loss). Journal of Economics, Business, and Accountancy Ventura, 17(3) : 417 - 428.

Santioso, L., \& Halim, S. (2013). Analisis pengaruh ukuran perusahaan, struktur kepemilikan dan rasio perputaran persediaan terhadap pemilihan metode persediaan pada perusahaan manufaktur go public di BEI tahun 2006-2010. Jurnal Akuntansi, 13(2) : 945-970.

Skinner, D. J. (1993). The invesment opportunity set and accounting procedure choice : preliminary evidence. Journal of Accounting and Economics, 16 : 407-445.

Soepriyanto, G. (2011). Faktor-faktor yang mempengaruhi variasi tarif pajak efektif perusahaan : studi terhadap perusahaan yang terdaftar di BEI tahun 2002-2006. Binus Business Review, 2(2) : 1025-1035.

Stickney, C. P., \& McGee, V. E. (1982). Effective corporate tax rates the effect of size, capital intensity, leverage, and other factors. Journal of Accounting and Public Policy, 1(2) : 125-152.

Sumarni, I., Yusniar, M. W., \& Juniar, A. (2014). Pengaruh Investment Opportunity Set Terhadap Kebijakan Deviden. Jurnal Wawasan Manajemen.

Syailendra, B., \& Raharja. (2014). Analisis faktor-faktor yang berpengaruh terhadap pemilihan metode penilaian persediaan (Studi kasus pada perusahaan dagang dan manufaktur yang terdaftar di BEI 
tahun 2008-2012). Diponegoro Journal of Accounting, 3(2): 1-12.

Tala, O. Y., \& Pontoh, W. (2012). Pengaruh profitabilitas, leverage, kepemilikan manajerial terhadap manajemen laba pada perusahaan manufaktur di bursa efek Indonesia (BEl). Jurnal Riset Akuntansi dan Auditing, 3(1): 31-62.

Utomo, R. B. (2015). Pengaruh leverage, bonus plan, dan risiko terhadap kebijakan akuntansi dengan kepemilikan manajerial sebagai variabel moderasi. Jurnal Akuntansi dan Manajemen, 26(1) : 1-10.

Utomo, S. (2011). Skema bonus dewan direksi dan aktivitas manajemen laba (Penelitian pada perusahaan manufaktur di BEI). Jurnal Dinamika Ekonomi dan Bisnis, 8(1) : 93-104.

Wibawa, A., Wilopo, \& Abdillah, Y. (2016). Pengaruh good corporate governance terhadap penghindaran pajak (Studi pada perusahaan terdaftar di indeks bursa SRI KEHATI tahun 2010-2014). Jurnal Perpajakan, 11(1): 1-9.

Wijaya, V. A., \& Christiawan, Y. J. (2014). Pengaruh kompensasi bonus, leverage, dan pajak terhadap earning management pada perusahaan yang terdaftar di bursa efek indonesia tahun 2009-2013. Tax \& accounting review, 4(1). 